\title{
AS CRIANÇAS E A ETNOGRAFIA: \\ CRIATIVIDADE E IMAGINAÇÃO NA PESQUISA DE CAMPO COM \\ CRIANÇAS
}

\author{
Emilene Leite de Sousa ${ }^{1}$
}

\section{Introdução}

Este artigo resulta de uma análise sobre metodologia, métodos e instrumentos de pesquisa utilizados na pesquisa de campo realizada entre os anos de 2012 e 2014 entre as crianças Capuxu no sertão da Paraíba, Nordeste do Brasil.

Esta pesquisa fundamentou minha tese de doutorado cujo objetivo era verificar a produção da pessoa e da identidade Capuxu através da fabricação dos corpos na infância (Sousa, 2014).

O povo Capuxu é um grupo camponês endogâmico que habita o Sítio SantanaQueimadas. Este povo vive da agricultura de subsistência e de outras ocupações esporádicas e se esforçam para manter o ethos camponês, a identidade Capuxu e a noção nativa de pessoa através de fortes investimentos feitos nos corpos das crianças.

Assim é que o corpo da criança é produzido para dar lugar à pessoa Capuxu, e estes processos de produção individuais e coletivos desembocam na fabricação de uma identidade coletiva de um povo que se autodenomina e é denominado de povo Capuxu. O etnônimo Capuxu faz referência a uma abelha que estaria presente na história de origem da comunidade em que um de seus antepassados chamado João tinha por hábito a caça da abelha capuxu tornando-se conhecido como João Capuxu tendo sido o apelido repassado aos seus familiares.

Como já aludi, esta comunidade elegeu a endogamia como sistema de casamento com união preferencial entre primos. Aspectos como onomástica, parentesco, sistemas de apadrinhamento, trabalho infantil, conhecimentos nativos e aprendizagem na infância Capuxu foram verificados por meio dos métodos e técnicas que apresento neste artigo.

\footnotetext{
${ }^{1}$ Universidade Federal do Maranhão, Brasil.
} 


\section{“Ô de casa": da entrada em campo}

"Ô de casa..." A minha voz ecoou na casa quase sem móveis, com a porta de cima aberta e a de baixo somente encostada. Lá de dentro ouvi uma voz fina e trêmula que gritava enquanto corria aproximandose cada vez mais: "Ô de fora..." Diante de mim uma criança de aproximadamente 3 anos e meio. Eufórica, hábil e curiosa, chegou antes mesmo dos adultos à sala. Suas feições foram de surpresa a vergonha quando se deparou comigo, de pé, em frente à porta. Recuou imediatamente com seus passinhos curtos para trás em busca do sofá enquanto me olhava. Escondeu-se por trás dele e pôs suas mãozinhas em cima do encosto. Eu sorria. Tudo isso não durou mais que uma fração de segundos. Sua mãe seguia seus passos vindo lá de dentro a reprová-la: "mas Denise é atrevida; ô menina atrevida!" Abriu um sorriso ao me ver, limpou suas mãos na saia antes de estender para mim a sua mão direita. Neste mesmo percurso, empurrou com os pés a cabeça de uma boneca que estava no chão. O nosso aperto de mãos fez-me sentir em casa mais uma vez.

Não fiquei lá mais do que uma hora. Na verdade, fui somente num "survey" revê-los e marcar as datas dos próximos encontros enquanto não me mudasse para lá. Durante a conversa acompanhei com o olhar os passos de Denise que, suja de terra, cobria sua nudez com uma calcinha. Lentamente ela se aproximou, afinal, a sala já estava cheia dos vizinhos (inclusive crianças) que não paravam de chegar. Escondeu seu rosto na saia da mãe que me falava. Depois, sentou-se no sofá envelhecido quase sem ocupar espaço. Aos poucos os vizinhos voltaram às suas casas e afazeres depois de terem me cumprimentado. Ficamos, portanto, eu e Denise na sala, enquanto a mãe dela preparava o almoço. Permaneci sentada na cadeira de balanço e tentei estabelecer contato perguntado o que, na verdade, já sabia: “qual seu nome?” Ela envergonhada sorria, mas não dava qualquer resposta.

Depois de um tempo e várias tentativas de diálogo frustradas, ela entrou por um segundo afastando com a mãozinha a cortina transparente que separava os cômodos. Senti-me fracassada: acabava de distanciar de mim uma de minhas primeiras informantes. Meu sentimento de incompetência se rompeu com o barulho de uma caixa de papel que vinha sendo arrastada pelo chão. Denise trouxe para sala seus brinquedos. Entendi que me fazia um convite. Sentei no chão frio - de cimento - ao seu lado, e comecei a tirar com ela seus brinquedos da caixa velha de papelão: o corpo nu da boneca cuja cabeça, suponho, estava no canto da sala. Um caminhão sem as rodas traseiras, os restos do que um dia foi um robô, uma bola furada, um fogão de plástico em miniatura, uma vassourinha do mesmo tamanho e mais uma série deles, todos deteriorados.

Demonstrava admiração a cada brinquedo retirado, indagando: "para que serve?" no intuito de que se sentisse a vontade, mas ela permanecia em silêncio. Interrompi minha tentativa de diálogo para almoçar, não poderia recusar, seria uma ofensa.

A tarde foi toda de visita às casas do local. As crianças sempre apareciam às calçadas ao ouvirem o ruído do carro da prefeitura que me conduzia até lá. Mas eu pensava, o tempo inteiro, quando retomaria com Denise a nossa aproximação. Temia que não conseguisse convencer as crianças a falarem comigo, afinal, sou apenas uma pesquisadora e adulta. Depois de visitar a quase todos, retomei o caminho para a cidade, e este, passava necessariamente, pela porta da casa de Denise. Lá estava ela, com a mesma calcinha sentada num acúmulo de terra em frente a sua casa, movendo caixas pequenas de margarina, garrafas e tampinhas.

Voltei o meu corpo no carro na tentativa de vê-la brincar sem se sentir observada. Mas estava enganada, ela havia me visto. Só descobri quando se pôs de pé, a abanar a mãozinha suja no sentido de um tchau. Enquanto lhe retribuía o tchau, eu sorri. Havia conseguido.

O desafio deste artigo, enunciado pelo grito de acesso às casas Capuxu, é uma reflexão sobre os percursos metodológicos escolhidos no caso de pesquisas com crianças. Para tanto, optei pelo uso da observação direta e do quadro conceitual da antropologia como guias teórico-metodológicos da pesquisa. A antropologia é uma ciência que não tem suas técnicas predeterminadas rigidamente, sendo necessário escolhê-las a cada vez, conforme as características e natureza dos problemas, 
construídos abstratamente pelo pesquisador, e que conformam o próprio objeto de estudo.

Assim, este estudo foi guiado pela observação direta e participante, garantindo a inserção do pesquisador na sociedade em análise (vivendo entre eles) e a interação deste com os atores sociais. A observação em campo está apoiada no conjunto de ações a que Cardoso de Oliveira (1998) chamou de olhar, ouvir e escrever, que garantiriam a apreensão pelo antropólogo dos principais aspectos culturais que envolvem o seu universo de agentes sociais. Na tentativa de apreender representações e práticas, a observação direta é essencial, pois nos permite associar o olhar e o ouvir, e entender os três níveis que compõem a vida cotidiana destas pessoas: o que dizem (discurso), o que fazem (ação), e o que pensam (representação) sobre o que fazem (Malinowski, 1984).

Através da observação direta aliada a outras técnicas, como entrevistas e conversas informais, eu pude dar conta da formulação da pessoa por meio dos processos de produção e transformação do corpo das crianças na vida cotidiana tendo este processo início desde a gravidez, e prosseguindo com o parto, a escolha do nome, dos padrinhos, o enterro do umbigo e sendo renovado a cada novo acontecimento que transforma o corpo, como a mudanças dos dentes de leite e a preparação para o trabalho agrícola.

A antropologia tem se dedicado cada vez mais a refletir sobre seus métodos de pesquisa, suas técnicas e instrumentos. Numa auto-reflexão, ela se despe constantemente de suas certezas e se questiona quanto à legitimidade da maneira como procede à investigação, bem como à relação entre pesquisador e sujeito de pesquisa, sendo a auto-análise uma das peculiaridades da disciplina. Mas, pouco se tem dito sobre a metodologia da pesquisa com crianças, especialmente com "crianças pequenas". Via de regra tornou-se clichê a máxima do "dar a voz" aos nativos, com ênfase no processo de pesquisa sobre o discurso ou o ouvir - como afirma Cardoso de Oliveira (1998).

Porém, que tratamento metodológico dar a pesquisa que toma como sujeitos também as crianças que ainda não possuem a fala concatenada, cujo discurso é caracterizado pelo vocabulário minguado e pouca articulação das ideias? Como estabelecer um diálogo com as chamadas "crianças pequenas" em campo? E até que ponto as técnicas tradicionais da pesquisa antropológica e seus instrumentos são úteis no caso da pesquisa com crianças? 
Essa reflexão metodológica tem como intuito lançar luz sobre a minha interação entre as crianças, o processo de elaboração da etnografia, o uso não tradicional que fiz das técnicas da antropologia e a utilização inusitada dos instrumentos, além de me permitir refletir sobre os obstáculos que se colocaram para mim em campo. Ademais, esse itinerário metodológico será guiado por duas categorias antropológicas, as de imaginação e criatividade, recursos utilizados para ultrapassar as fronteiras colocadas entre mim e meus sujeitos de pesquisa pela diferença de condição em campo.

Somente fazendo uso do recurso da imaginação e da criatividade - matéria prima que me foi ofertada pelas crianças - é que eu pude compor uma etnografia da produção da pessoa na infância Capuxu. Uma infância "narrada" por elas através de suas práticas, mas inventada no encontro criativo (Wagner, 2010) entre etnólogo e sujeitos de pesquisa, tendo como invólucro a imaginação. Talvez eu pudesse ainda, acrescentar aos elementos da criatividade e imaginação, um terceiro: a ingenuidade, e a nossa trilogia estaria completa. A ingenuidade pode servir como moeda de troca, como me serviu em inúmeras circunstâncias entre as crianças Capuxu.

Desde que cheguei entre os Capuxu tento de todas as maneiras me socializar com as crianças. Ser aceita por elas é fundamental para o desenvolvimento de minha pesquisa. Mas, as crianças - cujo processo de socialização ainda não alcançou as boas maneiras, cortesia e jogos de educação e diplomacia que impõe aos adultos, além da simulação, é claro! - são sinceras ao extremo e se não gostam de você, não disfarçam.

Aproximo-me como posso, compartilho os espaços da casa e do Sítio Santana, os banhos no Rio Goiabeira, os espaços do roçado e os seus instrumentos de trabalho e me esforço para conseguir compartilhar com eles suas brincadeiras e brinquedos.

Numa dessas brincadeiras, uma cantiga infantil ajudou-me a estar lado-a-lado com os meus sujeitos de pesquisa e finalmente dar-nos as mãos:

J Se passarinho voa eu também quero voar

Com o biquinho para o chão e as asinhas para o ar

O pé, o pé, o pé

A mão, a mão, a mão

Dê uma volta meu amigo aperte a mão do seu irmão J

E lá estava eu, girando em torno de mim mesma e apertando as mãos de todas as crianças cada vez que os parceiros de brincadeira giravam na ciranda. Como sempre, elas não recusaram o meu pedido desconsertado para que me deixassem brincar com elas.

Mas Ítalo se mantinha distante, arredio e desconfiado. Talvez com ranço por eu ter tirado da mãe dele e de seus amigos um pouco da atenção que lhe despendiam. Não gostava de mim e todas as tentativas que eu fazia de conquistar a sua amizade foram frustradas.

Eu vislumbrava em Ítalo a figura do informante qualificado (nos termos de Malinowski). Ele exerce uma espécie de liderança entre as crianças, em todas as brincadeiras. É comunicativo e conhece as brincadeiras e suas regras como ninguém. 
Quando não, mesmo nos casos em que se confunde, consegue convencer as crianças de que as novas regras, que acabara de inventar, são as que estão valendo.

A todos Ítalo informa, explica, explana... menos a mim! É só me ver que franze a testa, apressa o passo e faz uma cara de "eu não quero conversa e não gosto de você".

Cada vez que Ítalo me ignorava eu tinha vontade de arrumar as malas e partir. Intrigante como ele, sendo tão político, não fazia questão de ser meu amigo. Talvez exatamente por isso, afinal eu parecia uma rival em atenção já que desde que cheguei todas as crianças me cercam de manhãzinha até a noite, encantadas com meus diários de campo e minhas canetas coloridas, papéis, gravador e máquina fotográfica. Todos queriam ver e tocar meus instrumentos de trabalho, menos Ítalo, em pé na porta do quarto ou na porteira, à distância na sala, ou indo embora emburrado e ameaçando aqueles que não fossem com ele: "vou guardar minha bola...". Assim, seguiram-se as primeiras semanas em campo.

Certa manhã, ensolarada e quente, eu seguia em direção ao roçado onde já encontraria boa parte das crianças auxiliando pais e irmãos nas tarefas de limpa da terra e plantio.

No atalho estreito improvisado à enxada pelos homens Capuxu, encontrei Ítalo que caminha de volta para casa em busca de água potável para os irmãos que desde cedo roçavam a terra.

Ao se deparar comigo a sós, num caminho estreito por onde nos bateríamos provavelmente, Ítalo não disfarçou o aborrecimento, franziu a testa mais uma vez, apressou o passo e virou o rosto.

Já desolada com a situação que se repetia cada vez que eu me aproximava do menino, cansada de tantos desencontros etnográficos, eu tentava rapidamente encontrar uma forma de cumprimentá-lo, pelo menos para que soubesse que a presença dele era importante para mim. Na medida em que se aproximava de mim observei no pulso de Ítalo um relógio de tinta azul desenhado. Numa fração de segundos elaborei:

- Com licença! Que horas são, por favor?

Ele parou e me olhou de esguelha, assustado, depois, ato contínuo respondeu com um tom áspero na voz:

- Tá desmantelado!

Eu, imediatamente, complementei:

- Quebrou? Que pena...

Ítalo ergueu o braço esquerdo e olhando para o relógio de caneta azul desenhado no pulso suavizou o tom da voz:

- Pois é... entrou água!

Assim seguimos nossos caminhos contrários, mas de certo com um sorriso parecido no rosto. $\mathrm{O}$ meu, de quem finalmente começava a romper as barreiras que me separava como pesquisadora-adulta do menino camponês; o dele, de quem se vê reconhecido nos seus esforços inventivos e respeitado por um adulto na comunidade. Desde esse dia algo mudara entre nós dois. Ítalo não demonstrava aborrecimento quando me via e nem se mantinha distante. Até passou a ficar por perto e estar interessado nas coisas que eu dizia ou fazia com as demais crianças.

Com o tempo aproximou-se de mim e me ofereceu os seus brinquedos, sinal maior de que eu havia sido aceita por ele.

No final da pesquisa seguíamos sempre juntos para o roçado, o cipoal, o Rio Goiabeira. Brincávamos pelos cômodos da casa e por toda parte do Sítio. Sempre juntos, Ítalo era uma espécie de guia para mim e me acompanhava a todos os lugares enquanto me explicava sobre as brincadeiras, os caminhos $\mathrm{e}$ atalhos, os malassombros, as crianças, o roçado... adotava sempre uma postura de meu "secretário", como dizia.

Assim eu soube que estava certa desde o início. Seria Ítalo, aquele menino camponês de cinco anos, o meu informante qualificado. 
Conforme demonstro no fragmento acima, simulando minha ingenuidade em relação ao relógio imaginário de Ítalo, eu fui aceita por ele. Só assim eu pude entrar no jogo, por ter me submetido a fazer parte do imaginário do menino camponês. Mais ingênuo talvez seja o antropólogo que creia manipular os nativos, pois são eles que determinam posições para nós em campo e controlam as nossas impressões como queiram (Berreman, 1998).

Minha primeira dificuldade em campo foi aquela revelada pelo fragmento de meu diário: a minha aceitação pelas crianças. No caso de pesquisa com crianças, a entrada em campo é sempre mediada, porque autorizada, pelos pais e adultos em geral da comunidade. Mas a aceitação da pesquisa pelos adultos não significa o ser aceito pelas crianças. E sem a aceitação dos sujeitos não há pesquisa.

É importante ressaltar que as crianças camponesas Capuxu foram meus principais sujeitos, uma vez que o intuito desta pesquisa foi compreender a produção da pessoa tendo como possível via de acesso o corpo das crianças. Entretanto, não são as crianças os únicos sujeitos da pesquisa, pois estes processos de produção do corpo envolvem crianças, jovens e adultos, homens e mulheres, sendo todos estes sujeitos de pesquisa em potencial. Todavia, me esforço por tomar as crianças como sujeitos principais da pesquisa, por acreditar que elas têm uma agência em todo o processo de construção do corpo e da pessoa, agência esta que só se torna perceptível para o antropólogo disposto a observá-las, ouvi-las, interagir com elas. Entendo, pois, que em todo processo de construção do corpo da criança há uma cooperação, uma ação conjunta entre aqueles que são considerados responsáveis por produzir o corpo da criança e a própria criança dando sentido e atribuindo significado a estas ações dos adultos, além das construções produzidas pelas próprias crianças ou entre crianças.

Através das entrevistas e conversas informais os sujeitos que são considerados responsáveis por produzir o corpo da criança (sem negar a agência da própria criança) foram ouvidos, isto diz respeito também a toda a unidade doméstica: pais, irmãos, avós, tios, vizinhos, padrinhos, amigos.

Opto por tomar as expressões nativas "ô de casa" e "ô de fora" que dão acesso às casas Capuxu, lugar por excelência (mas não único) para a construção dos corpos, como categorias analíticas ou sociológicas, de modo que a primeira diz respeito à entrada do pesquisador em campo e a segunda equivale a interação, recepção das crianças com relação ao pesquisador e suas representações sobre ele. A primeira destas categorias 
trata de uma antropologia elaborada pelo antropólogo sobre os nativos; a segunda uma espécie de antropologia reversa (Wagner, 2010), das crianças sobre o antropólogo.

Ora, se não se produz o corpo das crianças Capuxu apenas em casa, mas por todos os espaços do Sítio Santana-Queimadas, minha pesquisa itinerante percorre os espaços do Sítio por onde estão as crianças, onde seus corpos se produzem e se deixam produzir, em busca de desvendar o complexo processo de formação do corpo e da pessoa Capuxu na infância.

A partir destas experiências, convido o leitor a percorrer comigo o caminho metodológico que me conduziu às crianças Capuxu, trajeto este caracterizado por atalhos, cortado por rios e cipoais, cercado de arame farpado e marcado pelas suas porteiras e fronteiras. Um caminho análogo àquele de toda pesquisa antropológica, cujos imponderáveis da vida real nos obriga, o tempo inteiro, a encontrar saídas do abismo que nos coloca. No caso da pesquisa que realizei entre as crianças camponesas, a imaginação e a criatividade me serviram como fio de Ariadne, e serão elas que conduzirão o leitor - como placas de sinalização a meio caminho - ao longo deste artigo.

\section{Ô de fora: da "menina que tirava fotos" à "menina que escreve um livro"}

Da minha primeira estadia entre os Capuxu, por ocasião de minha pesquisa de mestrado, de tudo o que fiz, perguntei, observei e registrei, nada teve um apelo tão forte sobre eles do que as fotografias que fiz. Por aquela época, as máquinas digitais ainda não eram comuns e as redes sociais não existiam, de modo que ser fotografado era algo ainda raro, só vez por outra quando algum fotógrafo da cidade passava por lá em sua moto, perguntando de casa em casa se alguém desejava tirar fotos. A escolha da família era sempre pelos filhos, com poucos recursos e sendo cara a fotografia, além de não ter feito nenhuma reserva, pois nunca se sabia quando o fotógrafo iria passar, os pais optavam por arrumar rapidamente a criança e fotografá-la para registrar o seu crescimento e poder mandar fotos para os parentes e padrinhos distantes.

Foi assim que eu, de posse de minha máquina fotográfica digital, seduzi adultos e crianças, me tornei a fotógrafa oficial da comunidade e me transformei na representação nativa na "menina que tirava fotos". Embora tenha enviado à Escola do Sítio a minha dissertação - ilustrada com diversas fotografias - eles pouco leram ou comentaram, mas as fotografias que fiz e distribuí foram guardadas, emolduradas, enviadas pelos correios, 
viraram motivos de histórias entre eles e uma lembrança guardada no imaginário das crianças pesquisadas que, por mais que se esforçassem, sendo pequenas demais à época não conseguiam se lembrar da "menina que tirava fotos".

Foi assim que me reapresentaram quando eu voltei dez anos depois. Assim me receberam, quase sem lembrar meu nome. Mas alguém sempre ia até o guarda-roupa ou estante da sala, para pegar uma das fotografias que eu havia feito e estender para mim.

Neste novo momento, me pus mais uma vez a explicar sobre o doutorado, a pesquisa e o enfoque da melhor maneira possível, e que eu precisava escrever uma tese, "é como um livro", arrisquei. E foi o bastante. Agora que toda família tem sua própria máquina digital e tudo é fotografado e enviado às redes sociais, fui abolida da posição de fotógrafa e me tornei "a menina que escreve um livro".

A partir de então, diante de qualquer acontecimento, de posse dos meus cadernos, tomando notas entre óculos de grau, canetas de cores diferentes e diários de campo, alguma criança sempre perguntava curiosa: "vai entrar no livro?”. Para cada registro, cada entrevista, cada anotação, cada evento, havia sempre a pergunta "vai entrar no livro?", sendo essa a frase que eu mais ouvi durante a minha pesquisa de doutorado entre o povo Capuxu. Para ilustrar o que agora digo, transcrevo um relato engraçado do meu diário de campo.

Hoje nas atividades da escola com as crianças decidi que faríamos parte de nossos trabalhos lá fora, ao ar livre. Pedi que as crianças me levassem onde quisessem, me mostrasse seu lugarzinho no Sítio, onde mais gostam de ficar. Decidiram, em conjunto, me levar ao açude de Dão, bem atrás da escola. Seguíamos todos juntos, em fila indiana. Algumas crianças na frente, eu mais ou menos no meio, outras poucas atrás de mim. Diante de um caminho íngreme, uma ladeirinha marcada por uma fenda, lembro de alguém ter gritado “cuidado!”, mas já era tarde. Mal consegui perceber que um grupo de quatro crianças despencavam ladeirinha abaixo. Pelo que entendi, a quarta delas na fila indiana escorregou e carregou consigo as outras três que cuidadosamente, joelhinhos flexionados, seguiam na frente. Acelerei o passo, tentando manter o mínimo de equilíbrio naquela descida tão íngreme e pensei, "que atalho eles escolheram!'. Quando me dei conta já estava lá embaixo, onde as quatro crianças que haviam rolado pareciam uma só, caídas umas por cima das outras. Por sorte ninguém chorava, mas todas elas exibiam a famosa "cara de choro". Tentavam se levantar descabeladas, joelhos e cotovelos ralados, havia areia por toda parte, incluindo olhos e bocas. E quando eu, ajudando os que tentavam se levantar, achei que havia visto de tudo, lá vêm Amanda, a mais gordinha das crianças, "desembestada", como eles dizem, descendo a ladeirinha de uma forma tão desengonçada e num ritmo tão acelerado que eu fui capaz de jurar que ela cairia sobre todos nós. Mas ela freou bruscamente diante daquele grupo de crianças machucadas, ofegante e séria, colocou as duas mãos na cintura, expressou com a testa franzida quase numa careta um "eeeittaaa". E finalmente olhando pra mim: "Vai entrar no livro?". 


\section{O que podem as crianças fazer pela etnografia?}

Contar uma história é também construir caminhos, inventar atalhos, selecionar imagens, desenhar lugares, narrar silêncios. Tudo isso requer não só o conhecimento da história que se deseja contar, mas a disposição em escolher os artefatos: métodos, técnicas e instrumentos através dos quais a história se torna passível de ser contada.

A inspiração para esta reflexão metodológica advém das minhas inquietações a respeito do como fazer a pesquisa. Talvez este empreendimento seja ainda mais penoso, pois pensar em como realizar a pesquisa pode tornar-se algo mais emblemático do que a simples tarefa de fazê-la, afinal, a construção etnográfica pode ser considerada uma daquelas tarefas cuja realização se dá pelos sentidos e a racionalização de sua feitura torna-se cara à antropologia. Uma dessas dificuldades se configura pelo fato de que só se tem a completa visualização de como ela foi feita quando ela alcança o seu fim, do mesmo modo como só se enxerga a construção através do qual a história foi narrada após a última palavra pronunciada. É assim que a linha de chegada torna-se, no trabalho de campo antropológico, um lugar de onde se começa a contar algo.

O meu esforço aqui é de - revisitando a etnografia e os meus diários de campo através da memória e dos registros que dela fiz - analisar o modo não convencional através do qual o pesquisador que investiga o universo infantil faz usos de técnicas e instrumentos. Estes usos inusitados desembocam num esforço epistemológico ainda maior no que se refere à construção de um texto permeado de faz-de-conta, narrativas confusas, fábulas com personagens inventados e desenhos aparentemente sem sentido que desafiam o pesquisador a transformar este universo narrado através das práticas infantis numa história coerente, fiel à realidade (do faz de conta) e formatada pelo rigor científico.

Assim é que esta reflexão se constitui numa tentativa de analisar os obstáculos à construção da escrita etnográfica em pesquisas feitas com crianças e não apenas sobre elas. Para tanto, eu parto de uma análise sobre o modo como a descrição etnográfica tem se dedicado ao ouvir, as narrativas e ao discurso para, a partir de então, problematizar as pesquisas com crianças cuja linguagem não é ainda articulada e o discurso assume outros dispositivos em vez da palavra. Especialmente no caso das "crianças pequenas" aquelas que ainda não falam - a etnografia terá a difícil tarefa de traduzir silêncios, de interpretar falas-entrecortadas, palavras mal pronunciadas e interlocutores 
monossilábicos numa tentativa de dizer o não dito. Trata-se, pois, de um processo de uma complexidade inaudita.

Por isso me dedico à transformação do olhar em escrita, à organização textual do visível: a descrição etnográfica, especialmente nos casos em que o discurso não é o principal aliado do pesquisador.

É nesse sentido que a descrição etnográfica é entendida enquanto escrita do visível (e do sensível), com cuidado particular de vigilância em relação à linguagem, já que se trata de fazer ver ou compreender com palavras não intercambiáveis (Laplantine 2004). A descrição etnográfica, portanto, exige observação, sensibilidade, inteligência, imaginação, para fazer emergir a lógica própria da cultura que se descreve. É um olhar fixado num texto que permite elaborar um saber: o saber característico do antropólogo.

O pesquisador que trabalha com crianças deve estar atento aos outros modos de dizer das crianças e as formas de descrever estes modos no texto. Se a palavra pronunciada e a narrativa coerente são penosamente descritas em um texto etnográfico, o que dizer do pesquisador cuja tarefa é descrever uma história não contada? Como dizer a palavra não dita? Como traduzir silêncios? E o desejo, ímpeto de falar de quem ainda não consegue?

A minha descrição da produção da pessoa Capuxu através da fabricação do corpo na infância me remete a um universo silencioso ou de gritos estridentes, falas entrecortadas e palavras que nem sempre correspondem às ações. Um universo de técnicas corporais apreendidas através dos usos e descobertas do próprio corpo. Com tanto uso do corpo, que ensina e aprende, entre pares e pelas práticas do cotidiano, a palavra se transforma num elo perdido, a ser (per)seguido pelo pesquisador. A descrição desse universo que se descortina é marcada pelo esforço contínuo de aprender/ouvir aquilo que as crianças não conseguem ou não desejam falar.

Por essa razão, essa descrição abandona gravadores e roteiros de pesquisa para dar as mãos às crianças na ciranda. Larga os diários e cadernos de campo às margens do rio para entrar na água e aprender delas as brincadeiras (técnicas corporais) do Rio Goiabeira ou simplesmente ficar sentada olhando para tijolos dispostos fingindo-ser uma televisão. Afetada pela condição de criança camponesa, pensei como Favret-Saada (2005) que o tempo da análise viria depois.

Uma descrição que arregaça barras de calças e mangas de camisas para segurar a enxada, “assim, não! Assim”, como me ensina a criança Capuxu que segura as minhas 
mãos sobre a enxadinha com as suas próprias mãos. Ontem, no final da tarde, no chão da sala de sua casa, era eu quem lhe segurava a mãozinha sobre a caneta que desenhava seu nome num papel. Essa descrição é manchada de comida e terra nos diários de campo; marcada com polegares sujos minúsculos nos cantos das folhas dos meus cadernos folheados pelas crianças; conduzida por uma cantiga de ninar que embala suas redes enquanto adormecem e orientada pelos desenhos de bichos feitos na areia. Uma descrição etnográfica feita de dentes de leites e palavras sem erres, de banhos de rio e tentativas de subir em pés de manga, de arame farpado e pés de feijão, de cavalos de pau, bonecas de espiga de milho e carrinhos de mão.

Através da pesquisa com crianças a antropologia pode repensar os seus métodos tradicionais de pesquisa, e se deixar descrever pelos caminhos dos sentidos. O meu argumento é de que as crianças são sujeitos relativamente autônomos, com elaborações próprias a respeito do mundo e representações da sua infância, constituindo-se em importantes sujeitos de pesquisa. Todavia, a antropologia pouco tem se debruçado sobre os modos de investigação da infância, as limitações dos instrumentos e técnicas tradicionais nestes casos, e a dificuldade de etnografar (estando lá ou estando aqui) o universo infantil.

Entretanto estas limitações podem ser favoráveis à teoria etnográfica se forem enfrentadas pelos pesquisadores que ousarem utilizar novas técnicas e se dispuserem a re-significar seus instrumentos. Quando os modos de proceder em campo se transformam, o texto também se transforma. Uma modificação nos usos de técnicas e instrumentos da antropologia incorreria numa descrição etnográfica sob novos moldes, muito mais atenta ao olhar do que ao ouvir, disposta a incorporar a fábula no seu conteúdo e interessada em contar histórias cuja veracidade não é verificável, nem tampouco importante. Foi isso que me ensinou a experiência com Ítalo que lia a hora em relógios de caneta desenhados no pulso; ou com as meninas que assistiam televisão sentadas diante de uma porção de tijolos e seguravam uma telha à guisa de controle remoto; com Eliane que corria sempre à galope num cavalo imaginário; ou com Júnior que afirmava subir em pés de milho para colhê-los.

Se o dispositivo principal das crianças para narrar essa experiência não é a linguagem, concatenada, articulada e coesa, como a utilizam os adultos, a antropologia deve, talvez, utilizar-se em seu metier dos mesmos mecanismos de que se utilizam as crianças para apreender aquilo que sua cultura julga importante e legitima: dos dados e 
expressões da sensibilidade, da imaginação e da intuição, daquilo que só pode ser captado sensorialmente e só pode ser entendido pela experiência narrada através da vivência contínua dos modos de ser criança Capuxu que repousa, acima de tudo, no ambiente que os cercam.

A razão pela qual a pesquisa com crianças demanda outro modelo de análise dos etnógrafos é o fato das crianças aprenderem do mundo e dizerem dele não através da oralidade, especificamente, mas através da experiência. Assim, a infância é caracterizada pela captura do mundo pela experiência e pela narração do mundo através de práticas. Esta particularidade exige do pesquisador que apreenda e dialogue com as crianças também através de suas práticas. $\mathrm{O}$ que se aprende através dos usos dos sentidos não pode ser ensinado através da oralidade. $O$ pesquisador que almeja saber sobre as crianças deve apreender delas como elas apreendem do mundo: pela experiência.

Isto se torna essencial no caso das crianças Capuxu que aprendem a se tornar crianças camponesas pelos sentidos, isto é, através do corpo. Pela experiência vivenciada pelos campos, com o ambiente e os animais, com a terra e as plantações. Especialmente no caso das crianças pequenas o corpo é o principal instrumento de apreensão e comunicação. Se não falam, apontam, mostram, tocam, evidenciam. Descobrem de si e do mundo através do corpo. Que sejam, pois, construídos textos etnográficos que tragam à tona a sensibilidade da infância sem palavras, dos diferentes modos de ser quando o fazer ainda não é dizer.

Percorrer o trajeto das crianças que ainda não falam não significa o abandono da palavra, mas o percurso de encontro a ela. O que fazem as "crianças pequenas" Capuxu não é negar as palavras ou calá-las (como o fazem às vezes os adultos), mas ir de encontro a elas, e durante isso, eleger outros meios de dizer de si.

Por isso proponho uma antropologia mais voltada para os sentidos, e isso é fundamental quando se tem crianças pequenas como sujeitos de pesquisa e em situações em que elas aprendem do mundo, das pessoas, da cultura em que estão inseridas e de si mesmas através dos sentidos (ou do corpo). Neste sentido concordo com Ingold (2000) que as percepções são essenciais na produção do conhecimento, pois não há produção do conhecimento desengajada dos mundos que habitamos. Assim, os processos perceptivos são fundamentais para a aprendizagem e a comunicação, especialmente no 
contexto Capuxu, razão pela qual defendo uma antropologia tão voltada às percepções de seus sujeitos quanto eles produzem seus conhecimentos e informam através delas.

Logo, essa descrição etnográfica é uma pretensão. Ela deseja dizer, não como se faz uma etnografia, mas do que ela pode ser feita. Ela apresenta os elementos de uma nova construção: os desenhos na areia aparentemente sem sentido; a palavra mal pronunciada; a lágrima que jorra por tudo e quase sempre impede o falar; o poder de ficar invisível durante uma brincadeira de se esconder; o medo de malassombro ${ }^{2}$.

Acredito que uma antropologia contemporânea, dedicada cada vez mais aos sons, aos sentimentos e afetos de seus sujeitos de pesquisa, pode tomar das pesquisas com crianças a lição de uma ciência antropológica sensível aos modos de dizer do outro (não apenas aos conteúdos do que dizem, mas a forma como o dizem).

A pesquisa com crianças nos instiga a utilização não convencional de técnicas e instrumentos, uma vez que as entrevistas não se fazem possíveis, cedendo lugar às conversas informais e à observação participante, e instrumentos como gravadores e máquinas fotográficas são utilizados também como senha de acesso às crianças.

\section{A etnografia enquanto transformação da experiência em texto}

A atividade de percepção é inseparável da atividade de nomeação, embora a segunda seja insuficiente. Neste sentido ao pesquisador cabe ordenar a realidade através de uma escrita que a torne comunicável e, mais do que isso, palavra legível, proferida a partir da construção de um texto que revele a experiência das distintas culturas e do próprio pesquisador com a realidade.

A etnografia é precisamente a elaboração e a transformação pela escrita desta experiência, é a organização textual do observável em que uma das funções é a luta contra o esquecimento. Por isso, a descrição etnográfica se fundamenta na observação, e conforma, antes de tudo, uma experiência.

A observação etnográfica é uma relação entre os objetos, pessoas, situações e sensações provocadas no próprio pesquisador, torna-se, pois, muito mais do que captura do visível; a descrição etnográfica é por sua vez, a elaboração linguística desta experiência. É a percepção que desencadeia um processo de descrição, mas esta última

\footnotetext{
${ }^{2}$ Categoria nativa derivada do termo mal-assombrado, que diz respeito aos medos das crianças. Foi profundamente analisada por Flávia Pires (2011), numa cidade há poucos quilômetros do Sítio SantanaQueimadas.
} 
consiste menos em transcrever e mais em construir, em estabelecer uma série de relações entre o que é observado e aquele que observa.

As capacidades de observação não implicam apenas o que é visível, mas também no que é sentido. A este respeito Favret-Saada utilizou a expressão "ser afetado" afirmando que ser afetado não é se sentir como o outro se sente, mas é se sentir afetado pelo que afeta o outro (Favret-Saada, 2005). Assim é que esta experiência de observação nos remete não apenas ao olhar, mas as sensações que acometem o pesquisador em campo. Praticar a observação etnográfica consiste em se permitir afetar por aquilo que importa ao outro, que o atinge e afeta. É preciso compartilhar não só espaços e lugares, refeições e rituais, mas deve haver uma reciprocidade de sentidos e experiências, compartilhamento de sensações entre pesquisador e sujeitos de pesquisa, sendo esta uma condição sem a qual não se pode vivenciar o campo.

A escrita etnográfica tenta dar conta da totalidade do que observamos. Toda inspiração etnográfica deseja atingir ao máximo as partes do todo que desejamos apreender. Nada deve ser negligenciado nem pelo olho que observa, nem pelo ouvido que escuta, nem pela palavra que designa. Trata-se de nomear a totalidade daquilo que apreendemos. Por isso a boa descrição visa à exaustão, à saturação e, sobretudo, à ordenação e à classificação.

Para Geertz (1989) fazer etnografia consiste em muito mais que transcrever textos, levantar genealogias, mapear campos, manter um diário e etc. Fazer etnografia diz respeito ao esforço intelectual do pesquisador em produzir uma descrição densa do objeto em estudo. Produzir uma descrição densa é a capacidade de seguir uma hierarquia estratificada de estruturas significantes em termos das quais o objeto de estudo é passível de interpretação e sentido.

Cardoso de Oliveira (1998) se dedica aos três atos cognitivos que fundamentam a etnografia - o olhar, o ouvir e o escrever, demonstrando como os três campos semânticos são processos. A escrita, longe de ser um produto final, que é consequência dos dois primeiros, é um processo que percorre todo o trabalho de campo. Afinal, o antropólogo escreve estando lá e aqui, embora entendamos que as escritas feitas em campo e no gabinete são diferentes em sua forma, embora compartilhem do mesmo conteúdo. ${ }^{3}$

\footnotetext{
${ }^{3}$ Esta diferença fica evidente quando feita a distinção entre a escrita no diário de campo ou caderno de campo que se caracteriza pelas impressões e sentimentos do pesquisador, e pelos chamados dados brutos adquiridos
} 
De fato, a escrita não consiste num produto, algo que resulta de um processo primeiro já encerrado - da observação - mas ela é também um processo, que tem vida própria e nos conduz a caminhos distintos, do que às vezes se buscava, durante o próprio processo. Por essa razão tantas vezes iniciamos a escrita sem ter consciência do lugar onde ela nos levará. Ademais a escrita atua como uma espécie de via de mãodupla entre o texto e o campo, por meio da memória e seus registros, através dos fragmentos do campo que o autor traz com ele - em fotografias desbotadas, genealogias de parentesco, manuscritos desordenados e imagens não reveladas, mas presentes na memória.

E todo texto etnográfico está submetido aos registros da memória, das narrativas dos sujeitos e do pesquisador, e em suma, ao que se escreveu. Por essa razão acredito que é mesmo o texto o artefato primeiro da construção do saber antropológico. Não aquele que nos torna doutos, escritos nos nossos gabinetes, sendo discutidos com nossos pares, mas aquela escrita feita em campo que luta contra o esquecimento: de um povo sobre suas origens e do antropólogo sobre aquilo que o tornou antropólogo.

\section{A descrição etnográfica sobre crianças}

Guarda num velho baú seus instrumentos de trabalho: um abridor de amanhecer; um prego que farfalha; um encolhedor de rios; um esticador de horizontes. (Barros, Manoel de, 2010).

O pesquisador que trabalha com crianças tem em seu percurso um grande obstáculo epistemológico que diz respeito aos usos de técnicas e instrumentos.

A entrevista, importante técnica etnográfica, não é útil no caso da pesquisa com crianças, por conta da dificuldade de narrar o mundo em palavras (Faria, Demartini \& Prado 2005; Kramer \& Leite 1996). As conversas informais viram grandes aliadas do pesquisador que investiga a infância por poder se desenrolar enquanto se brinca com eles, se trabalha ou se aprende, em qualquer ambiente e sem formalismos.

Com uma antropologia que enfatizou ao longo do tempo o ouvir, como lidar com uma descrição etnográfica que repouse mais na observação? Como falar sobre, através,

em campo, como sensos, genealogias de parentesco etc.; e a escrita no gabinete, que se transforma em produto final da pesquisa, conformada pelos rigores da academia. Esta última sofre uma vigilância epistemológica ainda maior do que a escrita, também orientada e ensinada pela academia, que preenche nossos cadernos e diários de campo. 
com aqueles que ainda não falam? Como interpretar os sentidos atribuídos pelas crianças sem o uso das palavras, através das palavras?

Neste caso a observação ao corpo é de grande importância, uma vez que uma pesquisa que se dedica a analisar a infância não pode esperar das crianças grandes narrativas. Mesmo para as que já falam, o processo de narração está sendo ainda construído e, para as que não falam, o corpo é um dos principais instrumentos através dos quais se comunicam. Afinal, há muitos modos de fixar o discurso no corpo.

Através do corpo as crianças Capuxu me informaram o layout do Sítio SantanaQueimadas, o percurso do Rio Goiabeira, os animais que habitavam o sítio. Tudo isso apontando com o dedo indicador, esticando os bracinhos, ficando na ponta dos pés, utilizando todo o corpo. Também através de desenhos que me informavam àquilo sobre o que as crianças não podiam falar.

Os desenhos foram feitos no Grupo Escolar do Sítio, especialmente às sextasfeiras quando o último tempo é reservado à recreação, que pode se dar de várias maneiras: com aulas de músicas, danças, brincadeiras de roda ou desenhos. As professoras da escola me cederam este tempo e enquanto conversava com as crianças de maneira informal, mesmo no espaço da sala de aula, eu tomava notas.

Pedi-lhes sempre que desenhassem sobre aquilo que elas mais gostavam, livremente. Depois observando os desenhos entendi que as crianças tinham uma percepção de que eu fazia pesquisa sobre o Sítio, como lhes disseram os adultos. Assim, entenderam que eu pesquisava o espaço e não as pessoas.

Por esta razão, os desenhos aparecem focando em geral a casa, seu entorno, plantas, animais de estimação, estradas, carros que passam pelas estradas, açudes. E vez por outra incluem as próprias crianças ou a família.

Os desenhos das crianças me guiaram por uma série de aspectos importantes a serem verificados na pesquisa, especialmente as representações dos espaços do Sítio, a relação deles com a casa e seus arredores, as estradas e os animais.

A elaboração dos desenhos aliada à observação em campo foi muito útil por revelar no dia a dia das crianças o modo como estas se relacionavam com seus animais por todos os espaços do sítio. Além disso, os desenhos elaborados na escola terminaram exercendo também a função de me socializar juntos as crianças, desenvolvendo atividades como esta com eles, além de anunciar as relações das crianças e os bichos. 
Na pesquisa sobre o universo infantil, o antropólogo se detém às imagens que lhe vêm à memória e recorre às imagens e aos registros que dela fez através das fotografias. Neste caso, as fotografias foram tiradas em alguns dos momentos de produção do corpo do bebê, nos primeiros dias após o nascimento, da mãe grávida, dos alimentos à mesa, das crianças na escola, na festa junina, nos rituais de batismo, no festejo de Sant'Ana e em muitas outras ocasiões. Mas não informavam com riqueza de detalhes aquilo que eu havia inserido no texto. Achava sempre que a imagem empobrecia o texto.

Ainda assim, além de funcionar como importante instrumento de socialização da pesquisadora com todo o grupo, uma vez que eu fazia circular as imagens, elas também eram contempladas por mim por longos momentos quando me dispunha a escrever sobre determinado tema. Através da contemplação das fotografias que fiz o texto era enredado, construído e traduzido das imagens fotográficas e da memória para a escrita.

As imagens da memória são aliadas do antropólogo que se esforça por captar uma palavra mal pronunciada, uma sílaba ou letra que não sai (nas faltas de erres), os jogos de palavras e até mesmo a invenção de uma nova língua: a língua-do-p.

Não só o corpo é utilizado pelas crianças Capuxu como uma linguagem singular, especialmente se não se sabe falar. Para as crianças maiores que já dominam o universo da fala, esse domínio leva a construção de outros dispositivos da linguagem, gerando uma língua eminentemente infantil: a língua-do-p. A língua-do-p é uma tentativa de se comunicar entre as crianças Capuxu através de uma linguagem secreta e, portanto, um código não-compartilhado pelos adultos. Entretanto, esta língua já foi do domínio deles quando criança e, se assim não o fosse, seria facilmente decodificada. A Língua-do-p consiste em preceder cada sílaba ou palavra de uma frase de um p, como no exemplo: “p-vo p-cê, p-vai, p-bus, p-car, p-á,-pgua,p-pra,p-mim?” Para a frase “você vai buscar água pra mim?”. Assim, as crianças se comunicam ao longo do dia entre si.

Deste modo é que o desafio do pesquisador se transporta entre as poucas palavras, o vocabulário minguado, as parcas frases e seus sujeitos monossilábicos até as brincadeiras com as palavras, as descobertas, a repetição, improvisação e inovação no processo de aprendizagem do falar. Por outro lado, as palavras infantis ocupam um espaço entre o real e o imaginário, numa dinâmica que exige do etnógrafo no texto a mesma oscilação. As palavras, entre o real e o imaginário, (das próprias crianças e do texto) revelam uma experiência cuja essência está exatamente nisso, no fato delas habitarem mundos vividos e concebidos, aqueles que residem na experiência vivida, e 
aqueles cuja imaginação dá forma. As crianças também jogam com as palavras e se fazem-de-conta é porque têm intenção de jogar. A investigação do universo infantil só se torna possível se o pesquisador se submeter aos seus jogos (brincadeiras) e jogos de faz-de-conta.

Interessada que estava em saber dos malassombros, ouvia das crianças histórias mirabolantes de como elas lutaram com fantasmas, enfrentaram o diabo, assustaram uma alma penada, ou simplesmente, encontraram com alguma alma e foram capazes de correr desesperados para dela fugir. Todas estas histórias eram ouvidas e registradas por mim, para analisar depois a importância do malassombro e entender sobre os cuidados com a alma, esta dimensão da pessoa Capuxu.

A canção infantil é também um importante recurso de pesquisa. Muitas crianças que já dominam a dimensão da língua, mas de forma precária, com uma linguagem desarticulada, às vezes revelam uma linguagem que só é coesa na canção infantil, na cantiga de roda, na cantiga de ninar. Uma linguagem relativamente articulada nas parlendas e nas tentativas de narrar histórias infantis, fábulas fragmentadas e sem coerência. E as cantigas infantis também contam histórias. São modos subjetivos de interpretar a vida ou formas de narrar o mundo! Cataloguei algumas destas canções e elas me ajudaram a entender melhor a preocupação com o meio ambiente, os animais e como as crianças se relacionavam com todos estes elementos colocados à sua volta. Se aqui não as apresento é muito mais pela falta de espaço do que pela importância que teve para a minha pesquisa. As cantigas infantis foram importantes fontes de pesquisa.

Se para Geertz (1989) “a cultura de um povo é um conjunto de textos, eles mesmos conjuntos, que o antropólogo tenta ler sobre os ombros daqueles a quem eles pertencem", penso que no caso da pesquisa com crianças, nós antropólogos estamos, em quaisquer circunstâncias, enxergando por cima ou de cima, o que nos obriga diversas vezes a nos abaixar para olhá-las nos olhos e assim, estabelecer um diálogo. Todavia, se ao antropólogo se permite ler algo, mesmo que sobre os ombros do nativo, só o faz pela permissão (às vezes simuladamente desinteressada ou incidental) do nativo, seja ele adulto ou criança.

Esta aceitação, com caráter incidental ou proposital, é fundamental por aliviar, embora nunca por completo, a solidão que o antropólogo vivencia em campo. Ser aceito minimamente nos permite compartilhar talvez a melodia do anthropological blues (DaMatta, 1978), uma espécie de "estarmos juntos" no "estar só". 
Mas arrisco dizer que entre as crianças Capuxu o meu anthropological blues teve outra sonoridade, em vozes estridentes nas cantigas infantis que podia ouvir pelos caminhos do Sítio, às margens do Rio, pelas janelas da escola, no roçado e por toda parte por onde estavam as crianças. Eram essas canções, que me vinham aos ouvidos enquanto escrevia nos meus diários, ou mesmo quando me balançando na rede tentava dormir. As canções falam de animais que compartilham com as crianças os mesmos espaços do Sítio, do corpo, de rios e plantas. Elas impulsionam as cirandas num movimento circular onde se transformam os elementos, cada criança a cada geração, mas sem nunca parar.

Depois de um tempo, sem nem ao menos saber de onde vinham as canções, se trazidas pelos ventos raros que sopram a mata do sertão paraibano, ou mesmo como ecos numa profusão de minhas memórias diárias, ouvi-las foi para mim como ouvir os tambores dos mortos de que fala Goldman (2006), eu podia senti-las mesmo quando ninguém as cantava e ninguém mais as ouvia.

Não apenas as técnicas de pesquisa se modificam no caso da pesquisa com crianças, mas também o uso dos instrumentos. O smartphone não só cumpriu sua função de gravar entrevistas, com pais, padrinhos, benzedeiras, ele foi fundamental para que me socializasse, afinal atraíra os pequenos para perto de mim, como ocorreu com todos os outros instrumentos que eu carregava. Crianças que desejam joguinhos, fazer fotografias, ver imagens, assistir vídeos e ouvir músicas.

Com as crianças Capuxu eu percebi a ilusão alimentada pelo antropólogo de que nossos instrumentos de pesquisa nos pertencem. São antes os nossos sujeitos que os descobrem e manipulam, que nos permitem usá-los ou não, através de uma recusa (que quase nunca é absoluta, pois toda recusa é uma possibilidade) ou condicionando os usos que faremos deles.

Embora a câmera digital tenha sido uma aliada para mim em campo, confesso que não tenho nas fotografias que fiz grandes aliadas do texto. Isto porque uma vez terminada à pesquisa e analisando cautelosamente as imagens cheguei à conclusão de que o complexo processo de produção do corpo era dinâmico demais para que fosse capturado pela fotografia, a dinâmica que eu conseguia inserir no texto parecia congelar diante de imagens de crianças que sorrindo mostravam a "porteira" na boca de onde se perdeu o dente de leite, apontavam casas malassombradas ou posavam juntos a padrinhos ou primos, seus cônjuges em potencial. Neste caso, a dinâmica das relações 
entre crianças e padrinhos, entre primos e cônjuges em potencial, e do processo de produção ou cura do corpo ficavam estáticas não podendo ser lidas pelas imagens que a tudo congelava.

Apesar de o meu gravador ter servido para que as crianças cantassem e se ouvissem; meus cadernos fossem o campo propício para as muitas declarações de carinho coloridas, que faziam para mim com meus próprios lápis de tinta; e a máquina fotográfica fosse útil para registrar aquilo que elas julgavam interessante, na verdade todos estes instrumentos reutilizados me foram úteis o tempo inteiro, como modo de manter as crianças por perto. Já que minha primeira dificuldade em campo foi a minha aceitação pelas crianças.

Se em minha bagagem levava além dos manuais de pesquisa de campo, tudo o mais que a academia me ofertou, o guia teórico-metodológico à minha disposição não previa não ser aceita pelas crianças. Logo, era minha tarefa criar mecanismos para que se cumprisse o meu processo de socialização. Para alcançar este objetivo, condição sine qua non da pesquisa, a única maneira foi "apelar" para a imaginação e criatividade. Ora, o obstáculo que para mim se impunha era o fato de ser pesquisadora-adulta. A minha condição de existência me distanciava das crianças.

A peculiaridade da posição das crianças no mundo e como isso afeta o pesquisador e o submete a esta dinâmica entre o real e a ficção fica evidente no fragmento de meu diário que descreve o meu encontro com Ítalo e o esforço criativo que fiz para que ele aceitasse uma aproximação. Não acredito ser possível a vivência plena dessa experiência em campo e o abandono dela no texto. Como compor o texto deixando de lado o itinerário que me conduziu a descoberta do modo infantil de ler o mundo?

Por isso, tive o cuidado de descrever sobre os malassombros, o universo de crenças e as figuras lendárias, tal qual me disseram as crianças, atentando para as formas de afugentá-los ou de enfrentá-los. Esforcei-me para experimentar o mundo tal qual elas o fazem, a partir daquilo que viam e faziam. Daquilo que experimentavam: isto inclui o medo de malassombro, o medo do Rio Goiabeira, o trabalho no roçado, a relação com os animais e tudo o mais. 
Além do meu encontro com Ítalo, poderia elencar uma série de outros episódios registrados em diários de campo em que fui obrigada a me inserir no universo das crianças e, com criatividade, compartilhar com elas a mesma imaginação. $\mathrm{O}$ fragmento abaixo reforça o esforço que fiz repetidas vezes para conseguir a aproximação almejada.

\begin{abstract}
Certa manhã encontrei um grupo de meninas que brincavam à sombra de uma árvore frondosa. Junto a elas, uma porção de tijolos, todos aparentemente ordenados, embora eu não pudesse entender a lógica em que estavam dispostos.

Aproximei-me e elas passaram a rir, intimidadas. Percebi que brincavam e arrisquei perguntar de que brincavam. Elas responderam: "de casinha". Assim pude entender a disposição dos tijolos, formavam um sofá, um centro de sala, um rack e uma televisão. Perguntei o que faziam e elas disseram que assistiam TV. O que está passando, indaguei? "O programa da Eliana". "Posso assistir com vocês?", elas disseram que sim, com sorrisinhos disfarçados por trás das mãozinhas sobre a boca. Divertem-se com o próprio faz de conta que criaram, pois as crianças brincam porque têm intenção de brincar.

Afastaram-se pouco a pouco no sofá de tijolos para que eu sentasse. E ali ficamos uma fração de segundos, olhando em direção a outra porção de tijolos que fazia-deconta ser a televisão. Ilane, de 2 anos, que ainda não falava, aproximou-se lentamente e estendeu para mim um pedaço de telha quadrado, bem cortado. Eu recebi sem entender direito do que se tratava, sorrindo as outras crianças completaram, - "Ah, o controle remoto". Passei eu mesma a sorrir do faz-de-conta imaginando que eu poderia mudar o canal. Denise, a menor delas, sentada no chão, entendeu que todas as crianças estavam, de certa forma, me dando algo. Levantou-se suja da areia onde sentara, e estendera colocando sobre a palma da minha mão o seu último biscoito redondo e, saiu em busca de mais, à galope, num cavalo imaginário.
\end{abstract}

O fato de eu desconhecer boa parte das tarefas cotidianas da vida no campo tornou as crianças minhas ensinadoras, assim elas me mostravam orgulhosas como prender as galinhas, limpar a terra, usar as ferramentas de trabalho, atravessar a nado o Rio Goiabeira, contar os porcos, alimentar os bichos e daí por diante. As crianças têm grande prazer em ensinar a bonecas, animais e pessoas, e tomavam conta de mim no espaço e no cotidiano que conheciam tão bem como se fosse eu a criança.

Por essa razão, ousei sempre explorar a minha ingenuidade em relação aos conhecimentos que as crianças detinham e eu não. E na medida em que eu me portava como elas - como uma criança que brincava sempre que elas desejavam (ou quase sempre), e estava interessada em tudo o que dizia respeito ao universo infantil Capuxu, entrando nos atalhos, cipoais, lugares aonde os adultos não vão e fazendo coisas que eles não fazem - mais elas se portavam como eu (a adulta) me dando sermões com o dedo em riste: "cuidado, você pode se machucar".

Os métodos que dispunha foram repensados e juntos com eles, seus instrumentos. As entrevistas, com seus roteiros previamente preparados, cederam lugar às conversas 
informais, quando as crianças me davam as informações mais importantes sobre si mesmas, ademais, as conversas informais são tão legítimas quanto as entrevistas. Relacionar-se no mundo, seja como for, é apropriar-se, e as conversas informais foi o meio pelo qual eu me apropriei do discurso das crianças.

Neste caso é muito mais fácil ouvi-las enquanto caminhamos, nadamos no Rio, nos balançamos no cipoal. Especialmente porque são as circunstâncias que oferecem o script de perguntas possíveis ao invés dos roteiros previamente formulados. O pesquisador tem que estar atento e disposto a correr atrás das crianças, especialmente depois que a curiosidade que as atraíam até nós é vencida e elas retomam seu cotidiano e rotina.

Assim é que o movimento do trabalho de campo com crianças é invertido constantemente. Nossos sujeitos de pesquisa não permanecem por muito tempo nos lugares onde nós os colocamos - como se fossem peças de um jogo de xadrez - e nem nós pesquisadores permanecemos por muito tempo nos lugares onde eles nos colocam. No caso das crianças, a ciranda nunca pára de se movimentar e o antropólogo também faz parte dela.

Nos primeiros dias de pesquisa elas se afastam desconfiadas e intimidadas, sempre buscando um adulto que as acolha. Passados alguns dias elas se aproximam lentamente atraídas por aquilo que o pesquisador trás com ele, pelo novo, desde suas roupas e acessórios, até os instrumentos de trabalho.

Depois, a timidez cede lugar à curiosidade que se intensifica e eles desejam verme de perto quase tanto quanto eu a elas. Os seus olhos descobriam em mim o diferente. As suas mãozinhas ansiavam por tocarem os meus pertences e os instrumentos de trabalho (laptop, smartphone, mp3, mp4, lápis, cadernos, máquina fotográfica, livros, etc.).

Por essa época, por onde eu andava me seguiam dezenas de crianças, brigando para ficarem mais próximas de mim quando sentada na calçada, disputando para saber em que casa eu almoçaria, e de quem seria amiga, como me perguntou certa vez, Ilane: "Você quer ser minha melhor amiga?". Foi assim que eu descobri que eu nunca seria apenas "a pesquisadora".

Apesar de ser colocada em movimento constante pelas crianças em campo, sem nunca permanecer sendo por muito tempo a mesma coisa, em geral, era preciso que eu me movimentasse com imensa cautela sabendo que qualquer movimento brusco poderia 
machucar uma criança por perto. Perto demais. Dedinhos dos pés embaixo da cadeira de balanço, corpos por cima do meu na rede de dormir, dedinhos das mãos me impedindo de fechar a porta do banheiro. Afinal, não são apenas os nativos que perdem a privacidade quando o pesquisador está em campo.

Se a realização das entrevistas foi dificultada pela inquietude das crianças, o uso do gravador conforme demonstrei não se fez dispensável. Este, junto à máquina fotográfica, se transformou em espécie de "senha de entrada" para mim no campo. Assim, o pesquisador que trabalha com crianças deve utilizar-se de técnicas diferenciadas para cada grupo que toma como sujeitos de pesquisa entre as crianças.

Com as maiores, acima dos cinco anos, eu conseguia estabelecer as conversas informais, elas me ensinavam suas brincadeiras, falavam do dia-a-dia, dos animais, dos apelidos, do roçado, das tarefas domésticas e da aprendizagem na escola. Mas as chamadas "crianças pequenas", ainda não frequentadoras da escola e cuja linguagem ainda não está articulada, nos fala através de suas práticas.

A ênfase em observar as crianças reside no conhecimento que tenho dos processos de construção do corpo que são ensinados e circulam também entre as próprias crianças, sem estar diante, necessariamente, da presença dos adultos. Se alguns destes processos são construídos pelos adultos antes que a criança possa intervir (como no enterro dos umbigos) outros são apreendidos através de outras crianças e são ensinados entre elas, além delas mesmas cumprirem a obrigação de exercer estes processos: como o nado, o ritual do dente de leite e especialmente, as influências do sobrenatural, além da formulação dos apelidos, as relações estabelecidas com os cônjuges em potencial, primos e padrinhos em geral.

Também cuidados gerais com o corpo, em relação a excreção, a higiene e a estética são compartilhados apenas por crianças que reproduzem em parte aquilo que percebem nos adultos, ou procedem em relação ao corpo e suas partes e excreções como o desejam desde que não haja um adulto por perto. Por isso é comum vê-las comer "meleca", retirar de si mesmo os piolhos e libertá-los para irem embora em vez de matálos, roer unhas, mexer nas genitálias, coçá-las e cheirá-las ou cortar o próprio cabelo. Todas estas técnicas de aprendizagem praticadas junto a outras crianças, em alguns casos com o apoio ou parceria destas, mas que são completamente repreendidas pelos adultos. 
Entretanto, todas estas práticas consideradas abomináveis pelos adultos fazem parte do processo de conhecer a si mesmo, descobrir os sabores do próprio corpo e seus odores, decidir o que fazer daquilo que nele é encontrado, e em geral todas estas descobertas são realizadas entre crianças e não com os adultos, que as repreendem sempre que possível.

Por isso, transitei entre os universos de produções corporais que ocorriam entre adultos e crianças, mas também somente entre crianças para auscultar aquilo que, somente a experiência com a infância permite descobrir.

A partir destas técnicas de coletas de dados e instrumentos de pesquisa, penso ter dado conta do meu objetivo geral: o de verificar como se dá a produção da pessoa Capuxu à luz da análise dos processos de fabricação dos corpos das crianças, e pude compor uma etnografia desta construção da pessoa em seus vários aspectos. A observação em campo deu ênfase a essas várias fontes de dados com base nas quais construí uma etnografia de como através da fabricação do corpo da criança nasce a pessoa Capuxu.

\section{Referências}

BERREMAN, G. "Etnografia e controle de impressões numa aldeia dos Himalaia" em Alba Zaluar Guimarães (Org.) Desvendando Máscaras Sociais. $2^{\mathrm{a}}$ edição. Rio de Janeiro: Livraria Francisco Alves Editora. 1998.

CARDOSO DE OLIVEIRA, Roberto. O trabalho do antropólogo. São Paulo/Brasília: UNESP/Paralelo 15. Pp. 17-35. 1998.

DAMATTA, Roberto. "O ofício do etnólogo ou como ter "Anthropological Blues" em Edson de Oliveira Nunes (org.). A Aventura Sociológica. Rio de Janeiro: Zahar Editores, pp. 23-35. 1978.

FARIA, A. L. G., DEMARTINI, Z. B. F. \& PRADO, P. D. (Orgs.) Por uma cultura da Infância: metodologia de pesquisa com crianças. Campinas, SP: Autores Associados. 2005.

FAVRET-SAADA, Jeanne. "Ser afetado". Tradução Paula Serqueira, Revisão Tânia S. Lima. Cadernos de Campo. 13: 155-161. 2005.

GEERTZ, Clifford. A Interpretação das Culturas. Rio de Janeiro: Editora Aplicada 1989. (1973).

GOLDMAN, Márcio. "Os tambores dos mortos e os tambores dos vivos: Etnografia, Antropologia e Política em Ilhéus, Bahia”. Revista de Antropologia 46(2): 445-476. 2006.

INGOLD, Tim. "Culture, Nature, Environment: Steps to an Ecology of Life", em Tim Ingold, The Perception of the Environment: Essays on Livelihood, Dwelling and Skill, London: Routledge, pp. 13-26/420-421. 2000.

KRAMER, S. \& LEITE, M. I. (Orgs.). Infância: fios e desafios da pesquisa. $3^{a}$ edição. Série Prática Pedagógica. Campinas: Papirus. 1996.

LAPLANTINE, François. A descrição etnográfica. São Paulo: Terceira Margem. 2004.

MALINOWSKI, Bronislaw. "Introdução: Tema, método e objetivo desta pesquisa" em Bronislaw Malinowski, Argonautas do Pacífico Ocidental. São Paulo: Abril Cultural (Coleção Os Pensadores). 1984. 
PIRES, Flávia Ferreira. Quem tem medo de mal-assombro?: religião e infância no semiárido nordestino. Rio de Janeiro: E-papers/ João Pessoa: UFPB. 2011.

SOUSA, Emilene Leite de. Umbigos enterrados: corpo, pessoa e identidade Capuxu através da infância. Tese de doutorado em Antropologia Social. Universidade Federal de Santa Catarina/UFSC, Florianópolis, SC, 422 p. 2014.

WAGNER, Roy. A invenção da cultura. São Paulo: Cosac Naify. 2010.

Recebido em: 26/03/2015

Aprovado em: 24/05/2015 